\title{
KAJIAN KARAKTERISTIK MASSA BATUAN TERHADAP KECEPATAN PEMBORAN ALAT BOR SANDVIK RANGER DX800
}

\section{STUDY OF ROCK MASS CHARACTERISTICS ON THE DRILLING SPEED OF THE SANDVIK RANGER DX800}

\author{
DBA. Andris ${ }^{1}$, Guskarnali $^{2}$, H. Oktarianty ${ }^{3}$ \\ 1-3Jurusan Teknik Pertambangan, Fakultas Teknik, Universitas Bangka Belitung \\ Gedung Dharma Pengabdian Kampus Terpadu, Bangka, Kepulauan Bangka Belitung, Indonesia \\ e-mail: ${ }^{1}$ diobagusaditama@gmail.com, ${ }^{2}$ guskarnali@gmail.com, ${ }^{3}$ oktariantyhaslen@gmail.com
}

\begin{abstract}
ABSTRAK
Analisa perbedaan karakteristik massa batuan terhadap kecepatan pemboran alat bor Sandvik Ranger DX800 dengan parameter berupa penentuan sifat fisik dan nilai Rock Mass Rating (RMR) yang akan dibandingkan dengan kecepatan pemboran untuk pencapaian target produktivitas. Tujuan penelitian ini ialah memberi solusi dan rekomendasi untuk pencapaian target produktivitas berdasarkan kecepatan pemboran dari masing-masing front penambangan. Kecepatan pemboran pada penambangan batu granit di PT Vitrama Properti memiliki kecepatan yang berbeda karena karakteristik massa batuan pada front penambangan blok A berada di kelas II sebesar 62-72 dengan analisa karakteristik massa batuan berupa batuan bagus, sehingga kecepatan pemboran sebesar 28,18-31,12 meter/jam dengan produktivitas 108120 lubang/minggu. Sedangkan, pada karakteristik massa batuan pada front penambangan blok B berada di kelas II sebesar 77 dengan karakteristik massa batuan bagus, sehingga kecepatan pemboran sebesar 24,13 meter/jam dengan produktivitas 84 lubang/minggu. Solusi untuk meningkatkan produktivitas adalah dengan meningkatkan waktu kerja efektif (WKE) dan pembagian target produksi dengan alat bor Furukawa PCR200, sehingga meningkatkan produksi pada front penambangan blok A sebesar 144 -146 lubang/minggu dan front penambangan blok B 146 lubang/minggu.
\end{abstract}

Kata Kunci: Karakteristik Massa Batuan, Pemboran, Granit

\section{ABSTRACT}

Analyze the differences in rock mass characteristics on the drilling speed of the Sandvik Ranger DX800 with parameters in the form of determining the physical properties and the value of the Rock Mass Rating will be compared with the drilling speed to achieve the productivity target. The purpose of this research is to provide solutions and recommendations for achieving productivity targets based on the drilling speed of each mining front. The drilling speed in PT Vitrama Properti granite mining had different speeds because the rock mass characteristics in mining front of block $A$ in class II of 62-72 with the analyze of rock mass characteristics was a good rock, the drilling speed 28.18-31.12 m/hour with the actual productivity 108-120 holes/week. While, the characteristics of rock mass in mining front of block B in class II of 77 with the analyze of rock mass characteristics was a good rock, the drilling speed $24.13 \mathrm{~m} /$ hour with the actual productivity 84 holes/week. The solution to increase productivity were to increase the effective working time and division of production targets with the Furukawa PCR200, so increased production in mining front of block A of $144-146$ holes/week and mining front of block B of 146 holes/week.

Keywords: Rock Mass Characteristics, Drilling, Granite. 


\section{PENDAHULUAN}

PT Vitrama Properti menerapkan sistem penambangan tambang terbuka dengan metode quarry, proses penambangan batu granit dibongkar menggunakan proses peledakan sampai batuan terberai dari batuan induknya yang massive sehingga dilakukan kegiatan pemuatan dan pengangkutan batu granit menuju unit pengolahan. Dalam pembuatan lubang ledak dilapangan PT Vitrama Properti menggunakan mesin bor Sandvik Ranger DX800 dengan kedalaman lubang bor yang ditetapkan perusahaan rata-rata 3 rod atau 10 $\mathrm{m}$ per lubang.

Pada penelitian ini dilakukan dengan metode pengambilan data lapangan berupa karakteristik geologi batuan, pengujian laboratorium untuk mendapatkan nilai densitas dan nilai kuat tekan, kemudian dilanjutkan pengamatan pada kegiatan pengeboran lubang, sehingga diketahui kinerja pengeboran disetiap lokasi. [1]
Rencana produksi pemboran secara optimal sebesar 146 lubang/minggu pada tahun 2019. Namun pada kenyataannya yang terealisasi hanya sebesar 137 lubang/minggu diakibatkan karena laju pemboran yang berbeda-beda pada tiap front penambangan

Penelitian ini bertujuan untuk menganalisis perbedaan karakteristik massa batuan terhadap kecepatan pemboran alat bor dengan parameter menentukan sifat fisik dan nilai Rock Mass Rating (RMR) pada front penambangan yang akan digunakan dalam penentuan produktivitas aktual pemboran.

\section{METODE PENELITIAN}

Lokasi penambangan batu granit berada di Bukit Nunggal, Desa Air Mesu, Kecamatan Pangkalan Baru, Kabupaten Bangka Tengah, Provinsi Bangka Belitung yang secara geografis terletak pada posisi $106^{\circ} 09^{\prime}$ $08,57^{\prime \prime}$ BT $-106^{\circ} 09^{\prime} 52,13^{\prime \prime}$ BT dan $02^{\circ} 12$ ' 55,79' LS$02^{\circ} 13^{\prime} 54,43^{\prime}$ LS. Peta lokasi penelitian ini dapat dilihat pada Gambar 1.

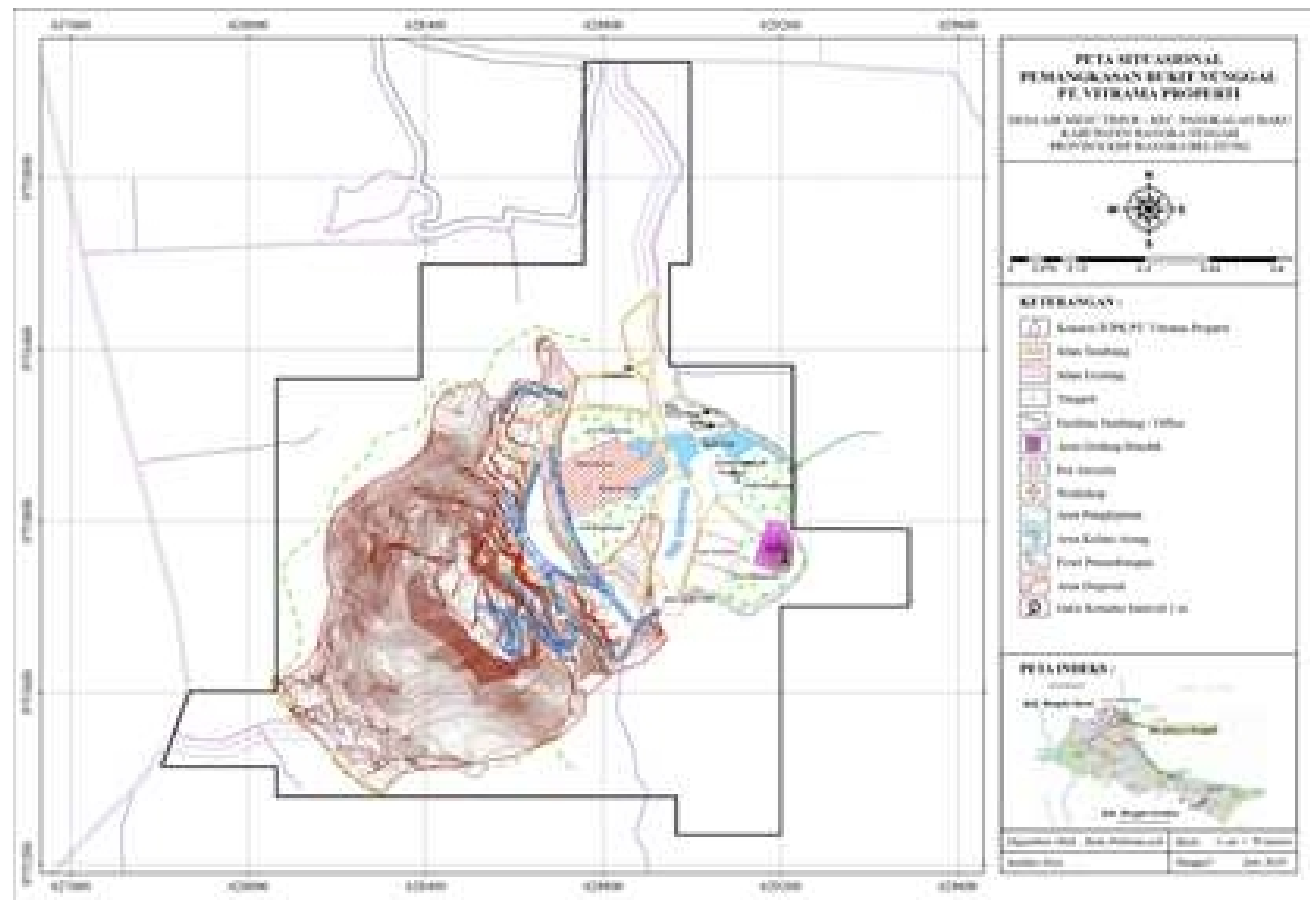

Gambar 1. Peta lokasi daerah penelitian

Pada penelitian ini menggunakan metode kuantitatif dan kualitatif berupa pengamatan langsung dan studi literatur yang terkait dengan kajian karakteristik massa batuan dan kecepatan pemboran. Penelitian ini diawali dengan pengambilan sampel batu granit berjumlah 6 batu untuk dilakukan preparasi agar berbentuk coring yang nantinya akan dilakukan pengujian kuat tekan berjumlah 4 sampel dan pengujian sifat fisik batuan berjumlah 2 sampel. Pengambilan data pengukuran bidang diskontinuitas pada bench di front penambangan blok A dan front penambangan blok B dengan metode scanline yang selanjutnya akan dilakukan analisa Rock Mass Rating (RMR). 
Metode Rock Mass Rating (RMR) awalnya telah dikembangkan di South African Council of Scientific and Industrial Research (CSIR) oleh Bieniawski berdasarkan pengalamannya di terowongan dangkal pada batuan sedimen [2]. Klasifikasi geomekanik didasarkan pada hasil penelitian 49 terowongan di Eropa dan Afrika, dimana klasifikasi ini menilai beberapa parameter yang kemudian diberi bobot (rating) dan digunakan untuk perencanaan terowongan dengan rumus dari perhitungan Rock Mass Rating (RMR) dengan menggunakan Per.(1).

$\mathrm{RMR}=\mathrm{A} 1+\mathrm{A} 2+\mathrm{A} 3+\mathrm{A} 4+\mathrm{A} 5+\mathrm{B}$

Keterangan :

A1 = Kekuatan batuan (rock strength)

A2 = Rock Quality Designation (RQD)

A3 = Jarak diskontinuitas

A4 $=$ Kondisi diskontinuitas

A5 = Kondisi air tanah

$\mathrm{B}=$ Orientasi diskontinuitas

Pada komponen Rock Mass Rating di atas berupa kekuatan suatu batuan dapat diperoleh dari pengujian Uniaxial Compressive Strengh (UCS) maupun Point Load Index (PLI) dengan sampel berbentuk coring dengan diameter $50 \mathrm{~mm}$ dengan tinggi tidak kurang dari dua kali diameter sampel. Tujuan utama pengujian ini adalah untuk klasifikasi kekuatan dan karakterisasi batuan utuh [3]. Hasil uji ini menghasilkan beberapa informasi yaitu; kurva tegangan regangan, kuat tekan uniaksial, Modulus Young, Nisbah Poisson, fraktur energi dan spesifik fraktur energi [4].

Jarak diskontinuitas dapat diartikan sebagai jarak rekahan antar bidang-bidang yang tidak sejajar dengan bidang-bidang lemah, serta pada kondisi diskontinuitas yang merupakan suatu parameter kemenerusan kekar, lebar rekahan kekar, kekasaran permukaan kekar, material pengisi kekar, dan tingkat pelapukan. Kondisi diskontinuitas ditentukan dari deskripsi tiap bidang diskontinuitas, berupa tingkat pelapukan, kekasaran permukaan bidang diskontinuitas, kemenerusan bidang kekar atau diskontinuitas, lebar bukaan, dan material pengisi bidang diskontinuitas [5].

Pengukuran kondisi air tanah pada front penambangan dapat dinyatakan secara umum seperti: kering, lembab, basah, menetes, dan mengalir. Penentuan kualitas massa batuan (rock quality designation) diperkenalkan oleh Deere pada tahun 1964 sebagai indeks penilaian kualitas batuan secara kuantitatif yang ditentukan dengan menggabungkan potongan inti yang panjangnya $100 \mathrm{~mm}$ (4 inci) atau lebih dalam satu meter lintasan bor. Inti baru yang rusak dipasang bersama dan dihitung sebagai satu bagian [6].
Orientasi bidang diskontinu dianggap menguntungkan jika berarah tegak lurus terhadap sumbu terowongan dan akan merugikan jika searah dengan sumbu terowongan [7]. Arah umum biasanya dinyatakan dalam strike/dip atau dip/dipdirection. Kedua nilai ini diperoleh dengan pengukuran menggunakan kompas geologi [8].

Setelah diperoleh data karakteristik massa batuan maka akan dilanjutkan dengan penguruan kecepatan pemboran, dimana kecepatan pemboran didapatkan berdasarkan pengolahan waktu edar alat bor Sandvik Ranger DX800, dari kedua data yang diperoleh tersebut akan dianalisis pengaruh karakteristik massa batuan terhadap kecepatan pemboran guna meningkatkan produktivitas aktual alat bor agar tercapainya target produksi yang ditentukan. Pada kegiatan pemboran untuk penyediaan lubang ledak umumnya dilakukan dengan mesin bor mekanik [9]. yang bertujuan untuk membuat sejumlah lubang ledak yang nantinya akan diisi dengan sejumlah bahan peledak untuk diledakan [10].

Produktivitas suatu alat bor untuk penyediaan lubang ledak menyatakan berapa volume batuan yang dapat dicakup atau dibor dalam waktu tertentu, sehingga produktifitas mesin bor dinyatakan dalam volume atau berat per satuan waktu $\left(\mathrm{m}^{3} / \mathrm{jam}\right.$, ton/jam) [11]. Hal ini menyatakan bahwa seluruh volume cakupan lubang ledak itu akan terbongkar ketika diledakkan. Produktivitas pemboran ditentukan berdasarkan waktu edar yang diperlukan oleh alat bor untuk menyelesaikan satu lubang bor, sehingga dapat dihitung dengan menggunakan Pers.(2).

$\sum \mathrm{Ct}=\mathrm{Pt}+\mathrm{Bt}+\mathrm{At}+\mathrm{St}+\mathrm{Dt}$.

Keterangan :

$\mathrm{Ct}=$ Waktu edar (detik)

$\mathrm{Bt}=$ Waktu pemboran (detik)

At $=$ Waktu mengangkat batang bor (detik)

St $=$ Waktu sambung batang bor (detik)

$\mathrm{Dt}=$ Waktu untuk mengatasi hambatan (detik)

$\mathrm{Pt}=$ Waktu pindah ke lubang yang lain (detik)

Selanjutnya perhitungan kecepatan pemboran untuk satu lubang bor dapat dihitung dengan menggunakan Pers.(3).

$\mathrm{Gdr}=\mathrm{H} / \mathrm{Ct} \times 60$

Keterangan:

$\mathrm{Gdr}=$ kecepatan pemboran (meter/jam)

$\mathrm{H}=$ kedalaman lubang tembak (meter)

$\mathrm{Ct}=$ waktu edar pemboran (menit) 


\section{Jurnal Pertambangan}

\section{HASIL DAN PEMBAHASAN}

Pada pengujian sifat fisik ini dilakukan dengan pengambilan sampel batu granit sebanyak 1 sampel dari front penambangan blok A dan front penambangan blok B, dalam pengambilan jumlah sampel tersebut dilakukan karena tidak ditemukan adanya variasi batuan granit dan tidak ditemukannya sisipan material pengisi pada bentang scanline, sehingga diperoleh data pengujian sifat fisik batu granit seperti pada Tabel 1 .

Tabel 1. Pengujian sifat fisik batuan

\begin{tabular}{|l|c|c|c|}
\hline \multicolumn{1}{|c|}{ Sifat Fisik Batuan } & Satuan & A & B \\
\hline Natural density & $\mathrm{gram} / \mathrm{cm}^{3}$ & 2,28 & 2,32 \\
\hline Dry density & $\mathrm{gram} / \mathrm{cm}^{3}$ & 2,28 & 2,31 \\
\hline Saturated density & $\mathrm{gram} / \mathrm{cm}^{3}$ & 2,33 & 2,35 \\
\hline Natural water content & $\%$ & 0,16 & 0,3 \\
\hline Degree of saturation & $\%$ & 6,67 & 16,67 \\
\hline Porosity & $\%$ & 5,4 & 4,15 \\
\hline Void ratio & & 0,06 & 0,04 \\
\hline
\end{tabular}

Data sifat fisik batu granit pada front penambangan blok B memiliki berat jenis, natural water content dan degree of saturation yang lebih besar dibandingkan front penambangan blok A yaitu berupa: natural density sebesar 2,32 gram $/ \mathrm{cm}^{3}$, dry density sebesar 2,31 $\mathrm{gram} / \mathrm{cm}^{3}$, saturated density sebesar 2,35 gram $/ \mathrm{cm}^{3}$, natural water content sebesar $0,3 \%$ dan degree of saturation sebesar 16,67\%. Sedangkan sifat fisik batu granit pada front penambangan blok A memiliki porosity dan viod ratio yang lebih besar dibandingkan front penambangan blok B yaitu berupa: porosity sebesar $5,4 \%$, dan void ratio sebesar 0,06 .

Front penambangan blok A terletak di puncak Bukit Nunggal dengan elevasi 179 - 222 mdpl yang memiliki luas wilayah sebesar $1,51 \mathrm{Ha}$. Koordinat lokasi berada di $106^{\circ} 09^{\prime} 18,21^{\prime \prime} \mathrm{BT}-106^{\circ} 09^{\prime} 22,17^{\prime \prime} \mathrm{BT}$ dan $2^{\circ} 13^{\prime}$ 34,21" LS - 2 ${ }^{\circ} 13^{\prime} 41,07^{\prime \prime}$ LS, ketinggian bench sebesar 7,35 - 9,25 m. Panjang scanline pertama sebesar $16 \mathrm{~m}$ yang ditentukan berdasarkan arah umum strike sebesar $\mathrm{N} 312^{\circ} \mathrm{E} / 74^{\circ}$ pada panjang pengukuran tersebut berada di atas bentang geometri pemboran dengan jarak ratarata kekar sebesar $0,53 \mathrm{~m}$. Sedangkan pada scanline kedua sebesar $10 \mathrm{~m}$ yang berdasarkan arah umum strike $\mathrm{N} 275^{\circ} \mathrm{E} / 83^{\circ}$ dengan jarak rata-rata kekar sebesar 0,4 dapat dilihat pada Gambar 2.

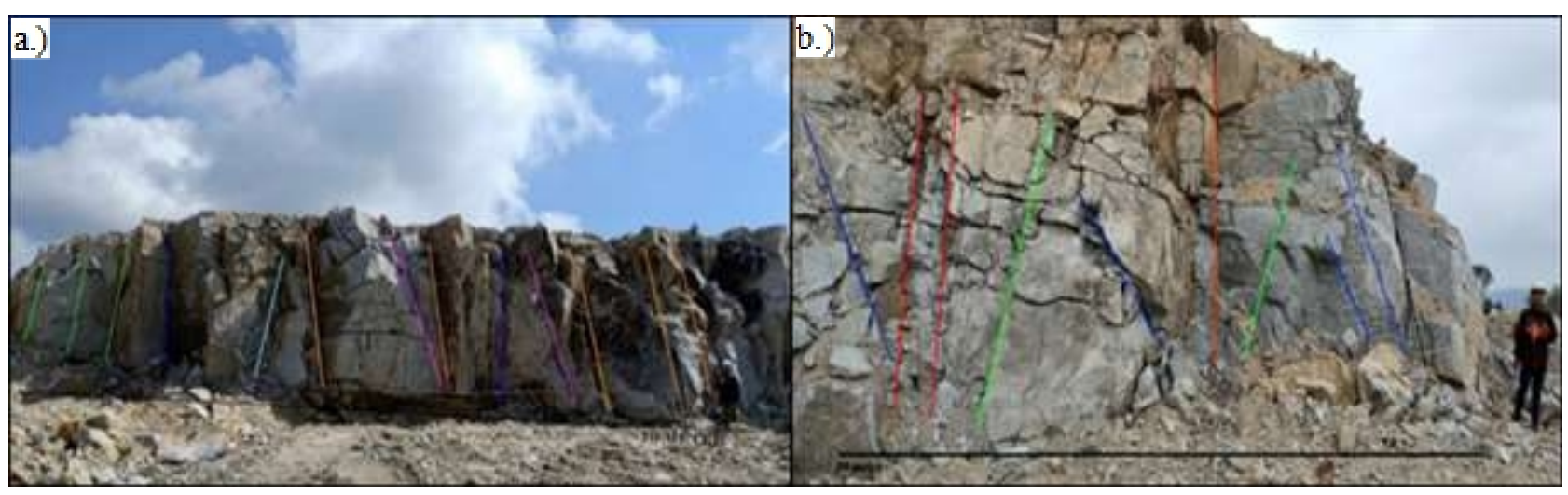

Gambar 2. Front penambangan blok A : a.) scanline pertama b.) scanline kedua

Front penambangan blok B terletak di kaki Bukit Nunggal dengan elevasi 85-115 mdpl yang memiliki luas wilayah sebesar $0,9 \mathrm{Ha}$. Koordinat lokasi berupa $106^{\circ} 09^{\prime} 21,02^{\prime \prime} \mathrm{BT}-106^{\circ} 09^{\prime} 23,40^{\prime \prime}$ BT dan $2^{\circ} 13^{\prime}$ 20,22" LS - 20 13' 26,37" LS. Panjang scanline pada front penambangan tersebut sebesar $15 \mathrm{~m}$ yang ditentukan berdasarkan arah umum strike sebesar $\mathrm{N}$ $271^{\circ} \mathrm{E} / 70^{\circ}$ dan panjang pengukuran tersebut berada di atas bentang geometri pemboran alat bor Sandvik Ranger DX800 dengan jarak rata-rata kekar per meter sebesar 0,38 m dapat dilihat pada Gambar 3 .

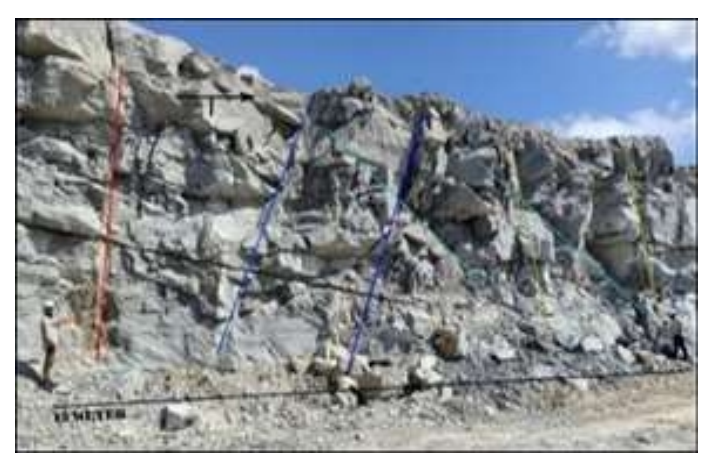

Gambar 3. Front penambangan blok B 
Terdapat beberapa parameter di dalam penentuan bobot kelas massa batuan berdasarkan metode Rock Mass Rating (RMR). Beberapa parameter tersebut memberikan bobot masing-masing yang selanjutnya akan dijumlahkan menjadi bobot total agar diketahui perbedaan karakteristik massa batuan dari masingmasing front penambangan yang nantinya akan digunakan dalam menganalisa kecepatan pemboran (rate penetration) alat bor Sandvik Ranger DX800 pada front penambangan blok $\mathrm{A}$ dan front penambangan blok B menggunakan metode Rock Mass Rating (RMR) dapat dilihat pada Tabel 2.

Tabel 2. Analisa Rock Mass Rating (RMR)

\begin{tabular}{|l|c|c|c|}
\hline \multirow{2}{*}{ Karakteristik Massa Batuan } & \multicolumn{3}{|c|}{ Front Penambangan } \\
\cline { 2 - 4 } & $\begin{array}{c}\text { Blok A } \\
(\text { Scanline Ke - 1) }\end{array}$ & $\begin{array}{c}\text { Blok A } \\
(\text { Scanline Ke - 2) }\end{array}$ & Blok B \\
\hline Kekuatan Batuan & 7 & 7 & 7 \\
\hline Rock Quality Designation & 20 & 20 & 20 \\
\hline Jarak Diskontinuitas & 10 & 10 & 10 \\
\hline Kondisi Diskontinuitas & 10 & 20 & 25 \\
\hline Kondisi Air Tanah & 15 & 15 & 15 \\
\hline Orientasi Diskontinuitas & 0 & 0 & 0 \\
\hline \multicolumn{1}{|c|}{ Jumlah Total } & 62 & 72 & 77 \\
\hline
\end{tabular}

Hasil pengujian kuat tekan 2 sampel batu granit pada front penambangan blok $\mathrm{A}$ diperoleh rata-rata kuat tekan sebesar 80,14 Mpa dan front penambangan blok B diperoleh rata-rata kuat tekan sebesar 90,52 Mpa dengan deskripsi batuan keras (strong), batu granit tersebut juga memiliki kandungan mineral berupa kuarsa $\left(\mathrm{SiO}^{2}\right)>70 \%$, sehingga mengakibatkan batu tersebut susah untuk terdeformasi. Front penambangan blok A dan front penambangan blok B memiliki frekuensi kekar yang relatif kecil yaitu sebesar 96,25 $97,33 \%$ dengan jarak diskontinuitas yang sedang (moderate) sebesar $0,38-0,53 \mathrm{~m}$ dengan orientasi diskontinuitasnya sangat menguntungkan (very favourable) berkisar $61,96^{\circ}-65,15^{\circ}$, dapat diketahui bahwa semakin panjang jarak antar kekar, maka semakin baik juga kondisi batuan tersebut.

Kondisi diskontinuitas pada front penambangan blok A dan front penambangan blok $\mathrm{B}$ memiliki penilaian kondisi diskontinuitas paling tinggi sebesar 25 dengan deskripsi berupa permukaan batu granit sangat kasar dan tidak mengalami pelapukan, dengan jarak pemisahannya sebesar $0,09 \mathrm{~mm}$, sehingga dapat diketahui bahwa kekasaran batuan pada analisa ini berfungsi sebagai pengunci permukaan antar bidang kekar satu dengan yang lainnya.

Kondisi air tanah pada front penambangan blok A dan front penambangan blok $\mathrm{B}$ dalam kondisi kering dengan tidak ditemukan adanya tetesan air karena pada pengujian sifat fisik batu granit sebelumnya diperoleh hasil pengukuran berupa: porositas hingga 5,4\% dan angka pori sebesar 0,06 yang sangat rapat serta tidak dapat ditembus oleh air, sehingga tidak memiliki kemampuan untuk menyimpan air. Karakteristik massa batuan pada front penambangan blok A dan front penambangan blok B memiliki karakteristik massa batuan yang bagus dan terdapat pada kelas II dengan nilai pembobotan RMR sebesar 62 - 77 .

Pengukuran produktivitas alat bor Sandvik Ranger DX800 dikaitkan dengan kecepatan pemboran dengan pengambilan data waktu edar (cycle time) pada front penambangan blok $\mathrm{A}$ dan pada front penambangan blok B, maka didapatkan data pengukuran kecepatan pemboran (rate penetration) berdasarkan pengaruh karakteristik massa batuannya pada masing-masing front penambangan dapat dilihat pada Tabel 3.

Tabel 3. Pengaruh Rock Mass Rating (RMR) terhadap kecepatan pemboran alat bor

\begin{tabular}{|l|c|c|c|c|c|}
\hline \multicolumn{1}{|c|}{ Front Penambangan } & $\begin{array}{c}\mathrm{H} \\
\text { (meter) }\end{array}$ & $\begin{array}{c}C T \\
\text { (menit) }\end{array}$ & $\begin{array}{c}\mathrm{V} \\
\text { (meter/jam) }\end{array}$ & Kelas & $\begin{array}{c}\text { Bobot } \\
\text { RMR }\end{array}$ \\
\hline Blok A (Scanline Ke-1) & 9,44 & 17,774 & 31,12 & II & 62 \\
\hline Blok A (Scanline Ke- 2) & 9,52 & 20,269 & 28,18 & II & 72 \\
\hline Blok B & 10,21 & 25,379 & 24,13 & II & 77 \\
\hline
\end{tabular}


Waktu edar pada scanline pertama di front penambangan blok A sebesar 17,774 menit/lubang dengan kedalaman lubang bor sebesar 9,44 meter, diperoleh kecepatan pemboran sebesar 31,12 meter/jam, maka diperoleh grafik pengaruh RMR terhadap kecepatan pemboran dapat dilihat pada Gambar 4.

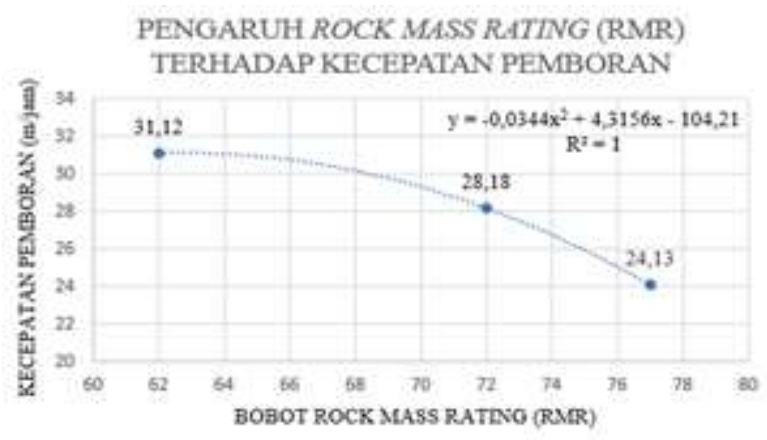

Gambar 4. Grafik RMR terhadap kecepatan pemboran

Optimalisasi produktivitas alat bor untuk tercapainya target produksi berupa pembagian target dengan alat bor Furukawa PCR200 yang mampu memproduksi lubang bor sebesar 2 lubang/jam dan penambahan waktu kerja efektif (WKE) dengan mengurangi waktu hambatan operator $(\mathrm{O})$.

Front penambangan blok B memiliki karakteristik massa batuan yang baik dengan bobot penilaian tertinggi sebesar 77 terdapat pada kelas II, sehingga kecepatan pemboran alat bor Sandvik Ranger DX800 hanya mencapai 24,13 meter/jam. Berdasarkan kecepatan pemboran tersebut maka akan diperoleh data produktivitas alat bor dari front penambangan blok A dan front penambangan blok B dapat dilihat pada Gambar 5.

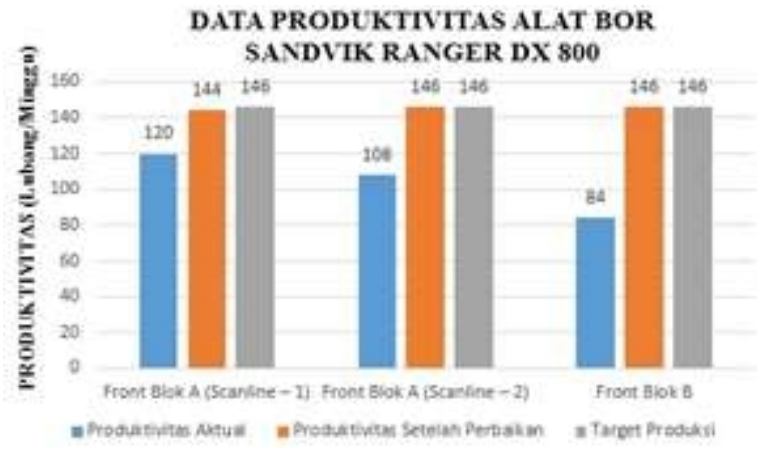

Gambar 5. Perbandingan produktivitas alat bor Sandvik Ranger DX800
Produktivitas aktual alat bor Sandvik Ranger DX800 pada scanline pertama di front penambangan blok A sebesar 120 lubang/minggu dan scanline kedua diperoleh produktivitas aktual sebesar 108 lubang/minggu, serta pada front penambangan blok B diperoleh produktivitas aktual sebesar 84 lubang/minggu.

Peningkatan produktivitas setelah dilakukan solusi perbaikan produktivitas alat bor berupa pada scanline ke - 1 pada front penambangan blok A sebesar 144 lubang/minggu dengan data pencapaian produktivitas mencapai 98,3\% dan scanline ke - 2 sebesar 146 lubang/minggu dengan data pencapaian produktivitas mencapai $100 \%$ dan front penambangan blok B mengalami peningkatan produktivitas sebesar 146 lubang/minggu dengan data pencapaian produktivitas mencapai $100 \%$.

\section{KESIMPULAN}

Front penambangan blok A dan front penambangan blok B memiliki karakteristik massa batuan yang bagus, pada front penambangan blok A berada di kelas II sebesar 62-72, sehingga kecepatan pemboran sebesar 28,18-31,12 meter/jam dengan produktivitas 108-120 lubang/minggu. Sedangkan, pada karakteristik massa batuan pada front penambangan blok B berada di kelas II sebesar 77, sehingga kecepatan pemboran sebesar 24,13 meter/jam dengan produktivitas 84 lubang/minggu.

\section{UCAPAN TERIMA KASIH}

Ucapan terima kasih diberikan kepada PT Vitrama Properti dan Universitas Bangka Belitung serta rekanrekan yang telah berkontribusi dalam membantu penelitian ini.

\section{DAFTAR PUSTAKA}

[1] Togar, Z. (2018). Hubungan Karakteristik Massa Batuan dan Unjuk Kerja Pengeboran Pada Tambang Batu Andesit di PT. Kalimantan Lestari Kabupaten Bandung Provinsi Jawa Barat. Skripsi, Fakultas Teknik : Universitas Islam Bandung.

[2] Singh, B, (2011), Engineering Rock Mass Classification. USA : Elsevier.

[3] Nata, RA., Sabri, Alfi., (2020). Block Punch Index (BPI) dan Point Load Index (PLI) untuk Memprediksi Nilai Kuat Tekan Batuan Penyusun Lereng Tambang guna Mencegah Terjadinya Longsoran di CV. Bara Mitra 
Kencana Sawahlunto, Jurnal Sains dan Teknologi, 20(01), 1-6.

[4] MA, Rai., S, Kramadibrata., RK, Wattimena., (2014), Mekanika Batuan. Bandung : ITB.

[5] Syam, MA., Heryanto., Trides, T., (2018). Analisis Kestabilan Lereng Berdasarkan Nilai Slope Mass Rating di Desa Sukamaju, Tenggarong Seberang Kutai Kartanegara, Kalimantan Timur, Jurnal Geocelebes, 02(02), 1-11.

[6] Hencher, S, (2015). Practical Rock Mechanics. CRC Press, New York, Hal : 14.

[7] Prengki, I., Heryadi, B., (2011). Analisis Beban Runtuh dan Evaluasi Lubang Bukaan Berdasarkan Metode Rock Mass Rating dan Q-System pada Tambang Bawah Tanah CV. Bara Mitra Kencana Sawahlunto, Sumatera Barat, Jurnal Bina Tambang, 03(04), 1-11.

[8] Desmawita, I., (2017). Analisis Kestabilan Lubang Bukaan Berdasarkan Klasifikasi Geomekanika Pada CV. Tahiti Coal Sawahlunto. Jurnal Bina Tambang, Universitas Negeri Padang, 03(01), 1-7.

[9] Gokhale, BV, (2011). Rotary Drilling and Blasting in Large Surface Mines. CRC Press, New York, Hal : 16.

[10] Putri, MH., Saismana, U., Hakim, RN., Radeng, M., Fikri, HN., (2017). Evaluasi Pemboran Penyediaan Lubang Ledak di Pit Warute PT Bukit Intan Indoperkasa, Jurnal Geosapta, 03(01), 1-4.

[11] Kesumawati, F., Nurhakim., Mustofa, A., Misdianto., (2014). Studi Target Pembongkaran Overburden Berdasarkan Kajian Pemboran untuk Lubang Ledak di PT Bukit Makmur Mandiri Utama Jobsite Adaro Kabupaten Tabalong Provinsi Kalimantan Selatan, Jurnal Fisika Flux, 11(01), 32 - 39. 